\title{
Effect of Risk Management Committee on Monitoring Mechanisms
}

\author{
Rachael Oluyemisi Arowolo*1, Ayoib Che-Ahmad ${ }^{2}$ and Oluwatoyin Muse Johnson Popoola ${ }^{2}$ \\ ${ }^{1}$ Chrisland University, Ajebo, Ogun State, Nigeria \\ 2 Tunku Puteri Intan Safinaz School of Accountancy, College of Business, Universiti Utara Malaysia, \\ Malaysia
}

\begin{abstract}
Corruption has become an identification label for many African countries of which Nigeria is one of the top listed countries. Monitoring mechanisms (MM) is therefore at the forefront of issues being considered by governments, company boards of directors, regulators, and management to ensure transparency, accountability, and protection of the shareholders' interests. Risk management is connected with components of internal control (risks assessment, monitoring, and control activities) which is a vital instrument to mitigate agency problems emanating from corruption and moral hazards in companies. It is, therefore, essential to understand Risk Management Committee (RMC) as one of the organisational attributes that can affect MM. The relationship between RMC and MM has not been empirically tested, particularly in Sub-Saharan Africa. Therefore, this paper examines the relationship between RMC and monitoring mechanisms. It provides empirical supports that RMC associates with monitoring mechanisms to reduce agency problems, using the data (2010-2012) of Nigerian nonfinancial listed companies. The board of directors of Nigerian companies is encouraged by this research to explore the usefulness of RMC in monitoring the management and controlling shareholders to lessen agency problems and protect the interests of the minority shareholders.
\end{abstract}

Keywords: Agency problem, corruption, monitoring mechanisms, risk management, developing country

JEL Classification Code: G33, G34, G35, M40, M42

Paper Type: Research

\section{INTRODUCTION}

The persistent economic downturn in local and global markets for which companies are continually experiencing failures and are merging due to the outcome of agency problems and corruptions that cuts across all levels of governance in a community (Cadbury, 1992) necessitates the study of monitoring mechanisms (Mustapha, 2009). The frequency of the 
incidence of fraud, corruptions, financial distress, business failures and mergers necessitates moves to ensure the fortification of the interests of the stakeholders of companies (Shichor, 2015). Safeguarding the interests of the stakeholders requires an intensive monitoring of the management and the controlling shareholders to reduce their opportunistic attitudes that constitute agency problems (Dockery, Tsegba, \& Herbert, 2012; Appah \& Emeh, 2013). In addition, it has also increased the awareness to manage risks and uncertainties in business (Yatim, 2010). This paper focuses on monitoring mechanisms as a summation of directorship, internal and external auditing and how they relate to risk management committee.

Although several studies had been conducted on monitoring mechanisms (MM), but only two (Mustapha, 2009; Anderson, Francis, \& Stokes, 1993) examine the three dimensions (i.e., directorship, internal and external auditing) in a study. The two studies are from developed and transiting countries, Australia and Malaysia. To the best of the knowledge of the authors, perhaps, none of the two studies examines the relationship between $\mathrm{MM}$ with risk management committee (RMC). Also, it is likely that country specifics may make a difference relating MM to RMC (Beneish \& Yohn, 2008).

Presently, Nigeria's population is about 186.99 millions of people (2016 World Population Review) with the ethnicity of about 250 languages (Curry, 2014). The country is highly rated for corruption as reflected in the Transparency International ( $\mathrm{TI}$ ) annual Corruption Perception Index (TI, 2003-2016). Likewise, there are daily news of corruption in newspapers and magazines as well as other social media (Premium Times Nigeria, 24 August 2017; Vanguard Newspaper, 5 November 2016). The graving and continuous incidence of fraud and corruption reflect the failure of many companies to effectively apply monitoring mechanisms capable of enhancing good corporate governance in Nigeria.

It is the responsibility of the Nigerian Securities and Exchange Commission (SEC) to regulate the Nigerian capital market to ensure the best corporate governance in companies. Even though, the Nigerian government has good laws, accounting, and financial standards, due process, and code of corporate governance in place such as Financial Reporting Council (FRC) Act, 2011; Independent Corrupt Practices and Other Related Offences Commission (ICPC), 2000; the Money Laundering (Prohibition) Act, 2004 among many others. The government, however, has failed to reduce fraud and corruption in Nigerian companies because of weak implementation and enforcement of the laws (Okobi, 2011; Arowolo \& Che-Ahmad, 2016). The failure of the implementation of good corporate governance has culminated in business failures (Shaikh, 2011; Rezzy, 2007), mergers (Akinbuli \& Kelilume, 2013), bankruptcy (Bernanke, 1983; Hassan, 2011), corruption, underdevelopment, unemployment, and poverty in Nigeria (Okpala, 2013).

This paper, therefore, empirically tests the relationship between risk management committee (RMC) and monitoring mechanisms as proxied by directorship, internal and external auditing. To the knowledge of the authors, this will be the first paper, perhaps, to examine monitoring mechanisms as a combination of directorship, internal and external auditing in the relationship with Risk Management Committee (RMC) in Nigeria. Mustapha (2009) examines organisational attributes (managerial ownership, block-holders, debt structure, information system structure, compensation structure, multinational status, and ethnicity) and the demand for monitoring mechanisms (directorship, internal and external auditing). This paper extends the study of Mustapha (2009) by introducing RMC. This study establishes that RMC impacts MM to reduce agency conflicts in Nigerian nonfinancial companies. The next section reviews the extant literature and hypotheses development after which the study presents methodology, results, discussion, and conclusions. 


\section{LITERATURE REVIEW}

\subsection{Monitoring Mechanisms}

Georgiev (2013) explores corruption in Bulgarian and documents that Monitoring Mechanisms (MM) are established to prevent and monitor fraud and corruption. However, the emphasis is more on the formative factors that determine the existence and spread of corruption. Thus, suggesting MM as a knowledge gap for further research. Huson, Parrino, and Starks (2001) examine the internal MM and CEO turnover and documents that MM helps to manage conflicts between management and shareholders as well as conflicts among shareholders. The study investigates only the directorship as MM, thereby, not testing the internal and external auditing. MM provides shareholders with the network to attain credible financial reports to secure their interests in companies where they invested (Malek \& Saidin, 2013). Only the studies of Mustapha (2009) and Anderson et al. (1993) examine MM combining directorship, internal and external auditing. However, none of the two examines the cause of Risk Management Committee on MM, even though, the global economic distress heightens the awareness for both. Nigerian Code of Corporate Governance (NCCG) highlights directorship, internal and external auditing as corporate monitoring mechanisms (SEC, 2011). This study adopts the costs of directorship, internal and external auditing suggested in the NCCG as the measurement for MM.

\subsubsection{Directorship}

This is the embodiment of the executive and non-executive directors in a company collectively referred to as the board of directors (Mustapha \& Che-Ahmad, 2011) appointed by the shareholders to supervise the management of the company (Jusoh \& Che-Ahmad, 2014). This is consistent with the NCCG directives in respect of the responsibilities of the board of directors in paragraphs 2 and 3 of SEC, 2011. The study of Fodio, Ibikunle and Oba (2013) on corporate governance mechanisms and reported earnings quality with data from 25 Nigerian listed insurance companies find that audit committee size, board size, and independence negatively associated with earnings management. Thus, the supervisory role of the board of directors suggests that they monitor the activities of the management, especially focusing on how to manage risks and uncertainties (see paragraphs 3.1.b, 9.2, 10, and 29 of 2011 SEC Code). The awareness of directorship supervisory role to reduce agency costs and manage risks notwithstanding, agency problems and consequences such as financial distress persist in Nigeria. Thus, there is a need to further examine directorship. This study, therefore, examines the cause of Risk Management Committee on directorship in aligning the interests of management with the shareholders.

\subsubsection{Internal Auditing}

Internal auditing is an internal monitoring mechanism designed to ensure adherence to financial reporting standards and accounting principles (Arowolo, 2016). It is designed for effectiveness and efficiency of companies' operations through positive criticism of weaknesses in the processes of the companies (Cohen \& Sayag, 2010). Abbott, Parker, \& Peters (2010) investigate how the oversight of audit committee relates to the internal function and nature of the function of the internal audit, using data from 134 New York Chief Internal Auditors. The study finds a greater internal audit function to justify the shareholders demand for better internal controls. All these are part of the extant literature examining how to use internal auditing to reduce agency problems and manage risks and uncertainties. Nigerian companies are required to put in place effective risk-based internal audit function in respect of internal control and risk management (SEC, 2011). Otherwise, 
they are to disclose the effectiveness of their internal processes and systems. However, the problem of agency conflicts persists in Sub-Saharan Africa, especially in Nigeria as evidenced by persistent financial distress. Hence, there is a need for more research on internal auditing. This study, therefore, examines internal auditing in the light of Risk Management Committee (RMC) in aligning the interests of management with the shareholders.

\subsubsection{External Auditing}

External auditing is the external monitoring mechanism that helps to ensure that companies comply with the due processing, accounting and auditing standards (AICPA, 2014). Thus, it is designed to produce reliable and quality financial reporting (Malek \& Saidin, 2013) by which it effectively guarantees financial credibility required to resolve agency problems (Hope, 2013). The Nigerian Codes of Corporate Governance, CAMA (1990 \& 2004 as amended), SEC Code (2011), NAICOM Code (2009) and CBN Code (2006) emphasise on the importance of the external auditing (Ofo, 2013), and therefore, mandate all listed companies to engage a statutory audit firm to annually audit their accounts (Arowolo, 2016). Likewise, PENCOM Code in paragraphs 4.3.13 and 5.2.1 highlight the importance of external audit in respect of audited financial statements (Arowolo, 2016). The existence of extant literature and Codes of Corporate Governance notwithstanding, agency problems evidenced in persistent financial distress, bankruptcy, and business merger in Sub-Saharan-Africa, Nigeria in particular calls for more research on external auditing. Therefore, this study examines external auditing as related to Risk Management Committee in aligning the interests of management with the shareholders.

\subsection{Underpinning Theories}

\subsubsection{Agency Theory}

Agency theory explains the relationship between the agents and the principals (Fama \& Jensen, 1983), thereby suggesting a corporation as a nexus of contacts (Jensen \& Meckling, 1976). It suggests that corporate governance helps to structure companies to attain their set objectives and monitor performance by reducing agency costs (Ikpefan \& Ojeka, 2013). It addresses moral hazards and information asymmetry (Hashim \& Devi, 2008). Thus, this paper adopts agency theory to explain the usefulness of monitoring mechanisms in reducing agency problems.

\subsubsection{Signalling Theory}

Signalling theory suggests that signals from a corporate's actions reflect the company's reputation (Tang, Lai, and Cheng, 2012). The signals found in actions and affairs of a company inform the kind of opinions that the stakeholders of the company form to evaluate the company's performance and value (Tang et al., 2012; Arowolo, 2016). Prior literature reveals that the theory helps to resolve information asymmetry problems (Bear, Rahman, \& Post, 2010). This paper finds signalling theory useful in identifying risks and security challenges embedded in managing moral hazards and information asymmetry and highlights the relevant monitoring mechanisms needed to manage the risks.

\subsection{Risk Management Committee}

Agency theory suggests moral hazards, information asymmetry, fraud, and corruption portends risks to the achievement of the corporate goal (i.e. maximise the shareholders' wealth). The theory also suggests that risk management committee (RMC) helps to fortify board monitoring, especially in risks related issues. Hence, it suggests that the board of 
directors (BOD) should oversee the affairs of the companies in the interests of the shareholders (Uadiale, 2010). The BOD works through a board committee, known as the RMC to manage the threats of the moral hazards and ensure high-quality monitoring (Subramaniam, McManus, \& Zhang, 2009). Signalling theory suggests that the presence of RMC in a company guarantees the shareholders that the BOD is strong enough to implement good corporate governance that aligns their interest with that of the management. The study of Subramaniam et al. (2009) documents that establishment of RMC could be of higher value in instances of increased risks in financial reporting and growth in company size. Yatim (2009) investigates RMC and board structures with data from 690 listed firms in Malaysia. The study finds that existence of RMC associates with strong board structures in the listed companies. Furthermore, RMC is established in companies where the board of director is committed to good corporate governance (Yatim, 2009).

This paper, therefore, highlights the significance of risk management committee (RMC) regarding board monitoring and affirms that RMC will demand more monitoring, rigorously scrutinises records and procedures in search of anomalies and risks, and takes

proper actions for risk management. More costs would accrue for adequate monitoring and risks management by taking actions that ensure that the company complies with relevant principles, standards, rules, regulations, and policies. This paper considers related hypotheses as shown below:

$\mathrm{H}_{1} \quad \mathrm{RMC}$ associates positively with the demand for monitoring mechanisms

$\mathrm{H}_{2} \quad \mathrm{RMC}$ associates positively with the demand for directorship

$\mathrm{H}_{3}$ RMC associates positively with the demand for internal auditing

$\mathrm{H}_{4} \mathrm{RMC}$ associates positively with the demand for external auditing

\subsection{Control Variables - Company Growth and Complexity}

The authors controlled for company growth and complexity.

\subsubsection{Company Growth}

It is emphasised in this paper that growth in the size of a company can portend risks, and if not well managed can create an avenue for management or controlling shareholders to explore and advance their opportunistic attitudes. Agency theory suggests that management are more empowered with the growth in the size of a company. Though growth is the major success index for a company and contributes to GDP of a country (Akinbuli \& Kelilume, 2013), it is with greater agency problems (Arowolo, 2016). This paper controls for growth because of its relevance to risks management and importance to the capital structure and national economy.

\subsubsection{Company Complexity}

This paper discusses the implication arising from increased complexity in a company's operation. Thus, it heralds risks that encourage opportunistic attitude by management or controlling shareholders. The Nigerian SEC Code (2011) directs that companies should consider the complexity of their operations in their decision for the board size. The study of Ferguson, Pinnuck, and Skinner (2013) shows that company complexity contributes to the audit market competition. Hess, Mohmann, and Stefani (2014) investigate the regulation of audit market, and characteristics of earnings using data from 29 countries. Their study reveals that complexity of the operation of companies affects audit quality. This paper, therefore, asserts that complexity as an organisational attribute will affect monitoring mechanisms for more monitoring will be required to ensure quality financial reports. 


\section{METHODOLOGY}

The researchers obtained data from 111 Nigerian non-financial listed companies using their annual reports for years 2010-2012, which is consistent with the approval and implementation date for 2011 SEC Code. The study collected data for internal auditing using questionnaire because the information is not in the annual reports of the companies. This study uses quantitative analysis to prove the validity and reliability of the hypotheses developed for the study based on established theories and empirical findings. The study used three-year data because of the limitation in obtaining long years' data using questionnaire. Some of the extant literature that used three years' data are Hashim and Rahman (2011), Himmelberg, Hubbard, and Palia (1999).

The paper analyses data using multivariate analysis to compare multiple response and explanatory variables. It measures the dependent variable (monitoring mechanisms) as the aggregate figure of the remunerations of non-executive directors, costs of internal and external auditing. The measurement for the internal auditing is the summation of the amount paid to the internal auditors while external auditing is the fees paid to the external auditors in years 2010 to 2012. This study follows Anderson et al. (1993) and Mustapha (2009) to measure the dependent variables. It scored companies with Risk Management Committee (RMC) as 1 and those with no RMC as 0 following Yatim (2010) study. It measured complexity as a proportion of inventories and receivables to total assets following Mustapha (2009). It uses Tobin's Q to test the association of company growth with monitoring mechanisms following Mustapha (2009). Thus, the data used is continuous except that of RMC that is categorical. The panel data model for this paper is as shown:

$$
\begin{aligned}
& M M i t=a i t+\beta 1 R M C i t+\beta 2 G R i t+\beta 3 C C i t+\mu i t+\varepsilon i t \\
& \text { Where: } \\
& \mathrm{MM}=\quad \text { Monitoring Mechanisms } \\
& \text { RMC = Risk Management Committee } \\
& \text { GR } \quad=\quad \text { Growth } \\
& \text { CC }=\text { Company Complexity }
\end{aligned}
$$

\section{RESULTS AND DISCUSSION}

This study collected data administering 332 copies of the questionnaire in 166 nonfinancial listed companies in Nigeria, giving one questionnaire to the internal auditor and one other to either the company secretary or the head of accounts, expecting to receive one of the two given to each company. The researchers collected the annual reports from the Nigerian Stock Exchange. Completed questionnaire was received from 117 companies, out of which 111 with corresponding annual reports were analysed as the other 6 companies were with no corresponding annual reports. The questionnaire consists observable items adopted from Mustapha (2009), Loh and Venkatraman (1992), Ho and Hutchinson (2010), Cohen and Savag (2010), Abott, Parker, and Peters (2010), and Wright and Charles (2012). The authors ran a descriptive analysis on SPSS 22 to explain the frequency, average score, minimum score, maximum score, and standard deviation of each variable. The study also employed Stata 13 to test the hypothesis using the panel data regression analysis technique.

$48.6 \%$ of the respondents are Internal Auditors, $38.7 \%$ are Company Accountants and the rest, $12.6 \%$ are the Company Secretaries of which $80.2 \%$ are male while $19.8 \%$ are female and $97.3 \%$ are Nigerian. Directorship is with a mean of $\mathrm{N} 23.03 \mathrm{~m}$, specifically $\mathrm{N} 19.14 \mathrm{~m}$ in 2010, N23.22m in 2011 and N26.73m in 2012, a minimum of N0.00, maximum 
of N496.5m (2010 $=\mathrm{N} 437.4 \mathrm{~m}, 2011=\mathrm{N} 496.5 \mathrm{~m}$ and $2012=\mathrm{N} 341.6 \mathrm{~m})$ and standard deviation of N54.49m $(2010=\mathrm{N} 4.3 \mathrm{~m}, 2011=\mathrm{N} 59.25$, and $2012=\mathrm{N} 55.58)$. Internal Auditing is with a mean of N18.61m, specifically N17.35m in 2010, N18.97m in 2011 and $\mathrm{N} 19.51 \mathrm{~m}$ in 2012 , with a yearly minimum of $\mathrm{N} 10.5 \mathrm{~m}$, a yearly maximum of $\mathrm{N} 50.5 \mathrm{~m}$, and standard deviation ofN11.73m $(2010=\mathrm{N} 10.62 \mathrm{~m}, 2011=\mathrm{N} 12.23 \mathrm{~m}, 2012=\mathrm{N} 12.28 \mathrm{~m})$. External Auditing is with a means of $\mathrm{N} 16.5 \mathrm{~m}$ specifically $\mathrm{N} 12.11 \mathrm{~m}$ in $2010, \mathrm{~N} 17.19 \mathrm{~m}$ in 2011 and N20.19 in 2012, minimum of N0.35, maximum of N174.4m (2010 = N120m, $2011=\mathrm{N} 165 \mathrm{~m}$ and $2012=\mathrm{N} 174.4)$, and standard deviation of N25.12 $(2010=\mathrm{N} 15.91 \mathrm{~m}$, $2011=\mathrm{N} 25.57 \mathrm{~m}$ and $2012=\mathrm{N} 31.05 \mathrm{~m})$. The means for risk management committee is 0.37 specifically 0.3 in 2010, 0.38 in 2011 and 0.42 in 2012, minimum of 0 , maximum of 1 and standard deviation is $0.48(2010=0.46,2011=0.49$ and $2012=0.5)$.

Table 1. Profile of the Respondents (i.e 111 Companies)

\begin{tabular}{llcc}
\hline Background information & Categories & Frequency & $\%$ \\
\hline \multirow{3}{*}{ Position } & Internal Auditor & 54 & 48.6 \\
& Accountant & 43 & 38.7 \\
& Company Secretary & 14 & 12.6 \\
\hline
\end{tabular}

Table 2. Descriptive Statistics for the Variables (Untransformed Data)

\begin{tabular}{|c|c|c|c|c|}
\hline Variable & Mean & Std. Dev. & Min & Max \\
\hline \multicolumn{5}{|l|}{ Continuous Variables } \\
\hline Directorship (A'm) & 23.03 & 54.49 & 0.00 & 496.50 \\
\hline Directorship 2010 (A'm) & 19.14 & 48.30 & 0.00 & 437.40 \\
\hline Directorship 2011 (N'm) & 23.22 & 59.25 & 0.00 & 496.50 \\
\hline Directorship 2012 (A'm) & 26.73 & 55.58 & 0.00 & 341.60 \\
\hline Internal Auditing Costs (N'm) & 18.61 & 11.73 & 10.50 & 50.50 \\
\hline Internal Auditing Costs 2010 (\#'m) & 17.35 & 10.62 & 10.50 & 50.50 \\
\hline Internal Auditing Costs 2011 (N'm) & 18.97 & 12.23 & 10.50 & 50.50 \\
\hline Internal Auditing Costs 2012 ( & 19.51 & 12.28 & 10.50 & 50.50 \\
\hline External Auditing Costs (N'm) & 16.50 & 25.12 & 0.35 & 174.40 \\
\hline External Auditing Costs 2010 (N'm) & 12.11 & 15.91 & 0.35 & 120.00 \\
\hline External Auditing Costs 2011 (A'm) & 17.19 & 25.57 & 0.35 & 165.00 \\
\hline External Auditing Costs 2012 ( $\left.{ }^{\prime}{ }^{\prime} m\right)$ & 20.19 & 31.05 & 0.50 & 174.40 \\
\hline Monitoring Mechanisms' Costs (N'm) & 58.13 & 75.66 & 11.66 & 609.50 \\
\hline Monitoring Mechanisms' Costs 2010 (N'm) & 48.60 & 59.94 & 11.66 & 491.00 \\
\hline Monitoring Mechanisms' Costs 2011 (N'm) & 59.38 & 81.81 & 12.05 & 609.50 \\
\hline Monitoring Mechanisms' Costs 2012 (N'm) & 66.43 & 82.64 & 11.86 & 528.30 \\
\hline Risk Management Committee & 0.37 & 0.48 & 0 & 1 \\
\hline Risk Management Committee 2010 & 0.30 & 0.46 & 0 & 1 \\
\hline Risk Management Committee 2011 & 0.38 & 0.49 & 0 & 1 \\
\hline Risk Management Committee 2012 & 0.42 & 0.50 & 0 & 1 \\
\hline
\end{tabular}

Note: Observations for each variable is 333 and 111 for annual $(2010,2011,2012)$ observations. All the amounts are in millions of naira ( $\left.A^{\prime} m\right)$ and billions of naira ( $\left.{ }^{\prime} b n\right)$.

The F-test of the model suggests statistical significance showing that the regression models for the relationship between risk management committee and monitoring mechanisms (MM) as well as dimensions of $\mathrm{MM}$, directorship, internal and external auditing fit the data. In addition, it suggests the existence of a linear relationship in each of the models.

Table 3 and 4 presents the results of the panel data regression model ran using Stata 13 after validating the questionnaire, running pilot test, the distribution and collection of main data, non-response bias test, early and late respondents test, data cleaning, descriptive statistics for the variables and normality test. The results in Table 3 show that the VIF is below 5 and the tolerance is above 0.2 while Table 4 reveals no close correlation in the relationship between the variables as all correlations are below 0.9. This study, therefore, concludes that there is no multicollinearity problem for the variables examined. 
Table 3. Variance Inflation Factors (VIF)

\begin{tabular}{lcc}
\hline Variable & VIF & 1/VIF \\
\hline Risk Management Committee & 1.03 & 0.970 \\
Growth & 1.03 & 0.967 \\
Complexity & 1.01 & 0.994 \\
Mean VIF & 1.02 & \\
\hline
\end{tabular}

\begin{tabular}{lcccc}
\multicolumn{4}{c}{ Table 4. Pearson Correlation } \\
\hline Variable & $\begin{array}{c}\text { Monitoring } \\
\text { Mechanisms }\end{array}$ & $\begin{array}{c}\text { Risk Management } \\
\text { Committee }\end{array}$ & Growth & Complexity \\
\hline Monitoring Mechanisms & 1.000 & 1.000 & & \\
Risk Management Committee & 0.096 & 0.167 & 1.000 & 1.000 \\
Growth & 0.025 & -0.032 & 0.065 & 1.000 \\
Complexity & -0.071 & & & \\
\hline
\end{tabular}

This paper ran the panel data regression analysis using the pool, fixed and random effects and panel-corrected standard errors (PSCEs) but chose PSCEs considering its robust nature (Beck \& Katz, 1995) and its capability to correct heteroscedasticity and autocorrelation problems (Bailey \& Katz, 2011). The result as shown in Table 5, Panel A suggests that risk management committee $(\beta=14.928, z=10.1, p=0.000)$ significantly affects monitoring mechanisms (MM) in the right direction at $1 \%$. Also, the control variable, growth $(\beta=0.485, z=1.85, p=0.065)$ significantly impact $M M$ in the right direction while complexity $(\beta=9.650, z=2.05, p=0.040)$ significantly impact $M M$ but in the opposite direction. The $z$ test for each of the variables is above the panel data threshold of 1.65 , and the p-values except for company growth are below $5 \%$.

The result in Table 5 Panel $B$ suggests that risk management committee $(\beta=7.982$, $z=3.66, p=0.000$ ) significantly affects directorship in the right direction at $1 \%$. The control variables, growth $(\beta=0.948, z=4.22, p=0.000)$ significantly impact directorship at $1 \%$ and complexity $(\beta=7.540, z=1.74, p=0.082)$ significantly impact directorship in the opposite direction. The $z$ test for each of the variables is above the panel data threshold of 1.65 , and the p-values except for company complexity are below $5 \%$.

The result as shown in Table 5, Panel $C$ suggests that risk management committee (RMC) $(\beta=3.778, z=5.3, p=0.000)$ significantly affects internal auditing in the right direction at $1 \%$. The $z$ test for RMC is above the panel data threshold of 1.65 , and the p-values are below $5 \%$.

The result as shown in Table 5, Panel $D$ suggests that risk management committee $(\beta=2.694, z=2.41, p=0.016)$ significantly affects external auditing in the right direction. Also, the control variable, growth $(\beta=0.401, z=4.22, p=0.000)$ significantly impact external auditing at $1 \%$ in the right direction. The $z$ test for each of the two variables is above the panel data threshold of 1.65 , and the p-values are below $5 \%$.

The results support hypotheses $\mathrm{H}_{1}, \mathrm{H}_{2}, \mathrm{H}_{3}$ and $\mathrm{H}_{4}$ that risk management committee (RMC) associates positively with the demand for monitoring mechanisms (MM) and MM's dimensions, directorship, internal and external auditing. The results are consistent with the extant literature (Yatim, 2009; Subramaniam et al., 2009; Arowolo, 2009; Sarens \& Abdolmohammadi, 2011). A further test segmenting companies with RMC from those with no RMC reveals that companies with the separate committee for risk management demand for more MM. The average monitoring cost of companies with RMC is $\mathrm{N67.6m}$ while that of the companies with no RMC is $\mathrm{N} 52.6 \mathrm{~m}$ giving a difference of N15m.Companies with RMC are spending more on monitoring to improve the overall corporate governance structure of the companies by identifying, measuring, and managing financial, operational and reputational risks. Having such a stand-alone committee to manage risks also helps them to monitor and control all business-related risks (uncertainty and consequences) threatening the achievement of companies' 
objectives. High-quality financial reports that could be produced with the existence of RMC in a company can help to restore the trusts and confidence the investors lost in the management of a company after the global economic meltdown and the persistent financial distress witnessed in Nigeria. It is evident that the roles of identification, evaluation, monitoring and controlling of risks that may confront a company require monitoring costs. RMC will demand more monitoring as indicated by the $p$-value at $1 \%$ significance.

Table 5. Panel Data Regression Analysis Results

\begin{tabular}{|c|c|c|c|c|}
\hline PANEL A Monitoring Mechanisms & Coef. & Std. Err. & $\mathbf{z}$ & $\mathbf{P}>\mathbf{z}$ \\
\hline Risk Management Committee & 14.298 & 1.415 & 10.1 & 0.000 \\
\hline Growth & 0.485 & 0.263 & 1.85 & 0.065 \\
\hline Complexity & -9.650 & 4.702 & -2.05 & 0.040 \\
\hline cons & 56.857 & 4.801 & 11.84 & 0.000 \\
\hline PANEL B Directorship & Coef. & Std. Err. & $\mathbf{z}$ & $\mathbf{P}>\mathbf{Z}$ \\
\hline Risk Management Committee & 7.982 & 2.181 & 3.66 & 0.000 \\
\hline Growth & -0.948 & 0.225 & -4.22 & 0.000 \\
\hline Complexity & -7.540 & 4.341 & -1.74 & 0.082 \\
\hline cons & 24.301 & 3.400 & 7.15 & 0.000 \\
\hline$\overline{\text { PANEL C Internal Auditing }}$ & Coef. & Std. Err. & $\mathbf{z}$ & $P>z$ \\
\hline Risk Management Committee & 3.778 & 0.713 & 5.30 & 0.000 \\
\hline Growth & -0.039 & 0.112 & -0.35 & 0.727 \\
\hline Complexity & -0.374 & 0.876 & -0.43 & 0.669 \\
\hline cons & 17.408 & 0.662 & 26.28 & 0.000 \\
\hline$\overline{\text { PANEL D External Auditing }}$ & Coef. & Std. Err. & $\mathbf{Z}$ & $\mathbf{P}>\mathbf{Z}$ \\
\hline Risk Management Committee & 2.694 & 1.120 & 2.41 & 0.016 \\
\hline Growth & 0.401 & 0.095 & 4.22 & 0.000 \\
\hline Complexity & -1.941 & 1.364 & -1.42 & 0.155 \\
\hline cons & 16.147 & 1.799 & 8.98 & 0.000 \\
\hline
\end{tabular}

Though the Nigerian code of corporate governance, gave companies the option to have a separate committee for risk management, it highlights the importance of the committee to good corporate governance in paragraph 10. Thirty-three of the companies were already with a stand-alone committee for risks management even in 2010, preimplementation period. Nine more companies joined in the year of transition, 2011, giving that 42 companies were with risk management committee (RMC) in the year 2011. Another 5 companies also established their RMC in 2012. Thus, RMC exists in 47 nonfinancial listed companies in the year 2012 as many were concerned about what to do to reduce corruption in the companies and other facets of Nigerian economy and governance.

A considerable and growing body of literature has investigated risk management committee (RMC) (Dabari \& Saidin, 2014; Sarens \& Abdolmohammadi, 2011; Abdulmalik \& Che-Ahmad, 2015) but none tested its relationship with monitoring mechanisms (MM) as a combination of directorship, internal and external auditing. Only Anderson et al., 1993 and Mustapha, 2009 tested the combination of directorship, internal and external auditing but did not test RMC. To the knowledge of the authors, none perhaps, has tested the association between RMC and MM. Therefore, more research is needed especially in Sub-Saharan Africa with consideration to cultural, political, economic and other endogeneity factors' difference.

\section{CONCLUSION}

This study adds to the literature on risk management committee (RMC), agency conflicts especially as it is likely to be the first study to test monitoring mechanisms in totality 
(directorship, internal and external auditing) in Sub-Saharan Africa, Nigeria in particular. The study finds that RMC associates positively with the demand for monitoring mechanisms (directorship, internal and external auditing). The primary contribution of the study is that RMC and the control variables (growth and complexity) significantly impact and complement monitoring mechanisms. These findings are useful for the board of directors, the shareholders, government and regulatory agents to ensure good corporate governance in the companies. The authors recommend a consideration of data from other sectors of the economy for further test of the relationship.

\section{REFERENCES}

Abbott, L. J., Parker, S., \& Peters, G. F. (2010). Serving Two Masters: The Association between Audit Committee Internal Audit Oversight and Internal Audit Activities. Accounting Horizons, 24(1), 1-24.

Abdulmalik, S. O. \& Che-Ahmad, A. (2015). The Effect of 2011 Revised Code of Corporate Governance on Pricing Behaviour of Nigerian Auditors. European Financial and Accounting Journal, 4(10), 45-65.

AICPA, (2014). Standards and Statements. American Institute of Chartered Public Accountants Retrieved from: http://www.aicpa.org/Research/Standards/Pages/default.aspx.

Akinbuli, S. F., \& Kelilume, I. (2013). The Effects of Mergers and Acquisition on Corporate Growth and Profitability: Evidence from Nigeria. Global Journal of Business Research, 7(1), 43-58.

Anderson, D., Francis, J. R., \& Stokes, D. J. (1993). Auditing, Directorships and the Demand for Monitoring. Journal of Accounting and Public Policy, 12(4), 353-375.

Appah, E., \& Emeh, Y. (2013). Corporate Governance Structure and Timeliness of Financial Reports of Quoted Firms in Nigeria. European Journal of Business and Management, 5(32), 34-45.

Arowolo, R.O (2016). The Mediating Effects of the Quality-differentiated Auditors on the Relationship between Organizational Attributes and Monitoring Mechanisms (Doctoral Dissertation, Universiti Utara Malaysia)

Arowolo, R. O. \& Che-Ahmad, A. (2016). Effect of Horizontal-agency-costs and Managerial Ownership on Monitoring Mechanisms. International Journal of Economics and Financial Issues, 6(7S), 186-191.

Bailey, D., \& Katz, J. N. (2011). Implementing Panel Corrected Standard Errors in R: The PCSE Package. Journal of Statistical Software, 42(CS1), 1-11.

Bear, S., Rahman, N., \& Post, C. (2010). The Impact of Board Diversity and Gender Composition on Corporate Social Responsibility and Firm Reputation. Journal of Business Ethics, 97(2), 207-221.

Beck, N., \& Katz, J. N. (1995). What to do (and not to do) with Time-Series Cross-Section Data. The American Political Science Review, 89(3), 634-647.

Bernanke, B. S. (1983). Nonmonetary Effects of the Financial Crisis in the Propagation of the Great Depression. The American Economic Review, 257-276.

Beneish, M. D., \& Yohn, T. L. (2008). Information Friction and Investor Home Bias: A Perspective on the Effect of Global IFRS Adoption on the Extent of Equity Home Bias. Journal of Accounting and Public Policy, 27(6), 433-443.

Cadbury, A. (1992). Cadbury Report: The Financial Aspects of Corporate Governance. Tech report, HMG, London.

Cohen, A., \& Sayag, G. (2010). The Effectiveness of Internal Auditing: An Empirical Examination of its Determinants in Israeli Organisations. Australian Accounting Review, 20(3), 296-307.

Cohen, J. R., Krishnamoorthy, G., Peytcheva, M., \& Wright, A. M. (2013). How Does the Strength of the Financial Regulatory Regime Influence Auditors' Judgments to Constrain Aggressive Reporting in a Principles-Based Versus Rules-Based Accounting Environment? Accounting Horizons, 27(3), 579-601.

Curry, T. (n.d). Culture Name, Nigerian Orientation. Retrieved from: http://www.everyculture.com/Ma-Ni/Nigeria.html. 
Dabari, I. J., \& Saidin, S. Z. (2014). A theoretical framework on the level of risk management implementation in the Nigerian banking sector: The moderating effect of top management support. Paper presented at the International Conference on Accounting Studies 2014, ICAS 2014, 18-19 August 2014, Kuala Lumpur, Malaysia.

Dockery, E., Tsegba, I. N., \& Herbert W. E. (2012). Does Ownership Structure Influence Firm Performance? Empirical Insights from an Emerging Market. Journal of Governance and Regulation, 1(4), 165-175.

Fama, E. F., \& Jensen, M. C. (1983). Separation of Ownership and Control. Journal of Law \& Economics, 26(2), 301-325.

Ferguson, C., Pinnuck, M., \& Skinner, D. J. (2013). Audit Pricing and the Emergence of the Big 4 : Evidence from Australia.(Dissertation, University of Melbourne)

Fodio, M. I., Ibikunle, J., \& Oba, V. C. (2013). Corporate Governance Mechanisms and Reported Earnings Quality in Listed Nigerian Insurance Firms. International Journal of Finance and Accounting, 2(5), 279-286.

Georgiev, L. (2013). Corruption - A Necessary or Surmountable Evil. Megatrend Revija, 10(1), 83100.

Gupta, P. P., Weirich, T. R., \& Turner, L. E. (2013). Sarbanes-Oxley and Public Reporting on Internal Control: Hasty Reaction or Delayed Action? Accounting Horizons, 27(2), 371-408.

Hassan, A. T. (2011). An Exploratory Evaluation of the Impact of Regulation on Corporate Governance Practice in Nigerian Banks. (Dissertation, London South Bank University).

Hashim, H. A., \& Devi, S. S. (2008). Board Independence, CEO Duality, and Accrual Management: Malaysian Evidence. Asian Journal of Business and Accounting, 1(1), 27-46.

Hess, B., Mohrmann, U., \& Stefani, U. (2014). Audit Market Regulation and Earnings Characteristics: Cross-Country Evidence on the Role of the Audit Market Structure. Paper presented at the annual meeting of the SASE Annual Conference, Northwestern University and the University of Chicago, Chicago, IL USA Online <APPLICATION/PDF>. 2014-12-09 from http://citation.allacademic.com/meta/p729080_index.html.

Himmelberg, C. P., Hubbard, R. G., \& Palia, D. (1999). Understanding the Determinants of Managerial Ownership and the Link Between Ownership and Performance. Journal of financial economics, 53(3), 353-384.

Ho, S., \& Hutchinson, M. (2010). Internal Audit Department Characteristics/Activities and Audit Fees: Some Evidence from Hong Kong Firms. Journal of International Accounting, Auditing, and Taxation, 19(2), 121-136.

Hope, O.-K. (2013). Large Shareholders and Accounting Research. China Journal of Accounting Research, 6(1), 3-20.

Huson, M. R., Parrino, R., \& Starks, L. T. (2001). Internal Monitoring Mechanisms and CEO Turnover : A Long-Term Perspective. The Journal of Finance, 56(6), 2265-2297.

Ikpefan, O. A., \& Ojeka, S. (2013). Corporate Governance as a Tool for Curbing Bank Distress in Nigeria Deposit Money Banks: Empirical Evidence. Retrieved from: http://pakacademicsearch.com/pdf-files/ech/519/4151\%20Vol\%204,\%20No\%2013\%20(2013).pdf. Research Journal of Finance

Jensen, M., \& Meckling, W. (1976). Theory of the Firm: Managerial Behavior, Agency Costs, and Ownership Structure. Journal of Financial Economics, 3, 305-360.

Jusoh, M. A., \& Che-Ahmad, A. (2014). Equity Ownership, Audit Quality and Firm Performance in Malaysia using Generalized Least Square Estimations Technique. Journal of Emerging Issues in Economics, Finance and Banking (JEIEFB), 3(1), 976-991.

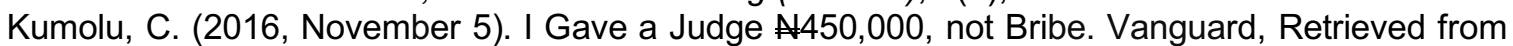
http://www.vanguardngr.com/2016/11/gave-judge-n450-000-not-bribe-usoro/.

Li, J., Mangena, M., \& Pike, R. (2012). The Effect of Audit Committee Characteristics on Intellectual Capital Disclosure. The British Accounting Review, 44(2), 98-110.

Loh, L., \& Venkatraman, N. (1992). Determinants of information technology outsourcing: a crosssectional analysis. Journal of Management Information Systems, 9(1), 7-24.

Malek, M., \& Saidin, S. F. (2013). Audit Services Fee, Non-Audit Services and the Reliability of Earnings. International Journal of Trade, Economics, and Finance, 4(5), 259-264.

Mustapha, M. (2009). Organisational Attributes and Corporate Monitoring Mechanisms. (Doctoral Dissertation, Universiti Utara Malaysia). 
Mustapha, M., \& Che-Ahmad, A. (2011). Agency Costs of Debt and Monitoring. International Review of Business Research Papers, 7(4), 118-129.

Ofo, N. (2013). External Auditors and the Codes of Corporate Governance in Nigeria. Retrieved from: http://thecorporateprof.com/code-of-corporate-governance-in-nigeria-2011-andinternational-best-practices-on-corporate-governance.

Ogundipe, S., \& Adebayo, H. (2017, August 24). Police tackle Nigerian senator who raised allegations of pay-for-promotion. Retrieved from:http://www.premiumtimesng.com/news/headlines/241435-police-tackle-nigeriansenator-raised-allegations-pay-promotion.html\#comments.

Okobi, N. (2011). Financial Reporting Council of Nigeria Act 2011: An Improvement in Corporate Governance Compliance in Nigeria's Banking Industry? International Bar Association, CSR E-Bulletin, October.

Okpala, K.E. (2013). Public Accounts Committee and Oversight Function in Nigeria: A Tower Built on Sinking Sand. International. Journal of Business and Management, 8(13), 111-117.

Rezzy, O. (2007). Sarbanes-Oxley: Progressive Punishment for Regressive Victimization. Retrieved from: http://ssrn.com/abstract=978834.

Sarens, G., \& Abdolmohammadi, M. J. (2011). Monitoring Effects of the Internal Audit Function: Agency Theory versus other Explanatory Variables. International Journal of Auditing, 15(1), $1-20$.

Shaikh, A. (2011). The First Great Depression of the $21^{\text {st }}$ Century. Socialist Register, Fall, 44-63.

Shichor, D. (2015). Financial Misrepresentation and Fraudulent Manipulation. The Routledge International Handbook of the Crimes of the Powerful), 278-288. Retrieved from: https://books.google.com.ng/books

Subramaniam, N., McManus, L., \& Zhang, J. (2009). Corporate Governance, Firm Characteristics and Risk Management Committee Formation in Australian companies. Managerial Auditing Journal, 24(4), 316-339.

Tang, A. K., Lai, K. H., \& Cheng, T. C. E. (2012). Environmental governance of enterprises and their economic upshot through corporate reputation and customer satisfaction. Business Strategy and the environment, 21(6), 401-411.

Transparency International (2013). Corruption Perception Index (CPI, 2012). Retrieved from: http://www.transparency.org/research/cpi/overview.

Transparency International (2014). Corruption Perception Index (CPI, 2013). Retrieved from: http://www.transparency.org/research/cpi/overview.

Transparency International (2015). Corruption Perception Index (CPI, 2014). Retrieved from: http://www.transparency.org/research/cpi/overview.

Transparency International (2016). Corruption Perception Index (CPI, 2015). Retrieved from: http://www.transparency.org/research/cpi/overview.

Uadiale, O. M. (2010). The Impact of Board Structure on Corporate Financial Performance in Nigeria. International Journal of Business and Management, 5(10), 155-166.

Wright, M. K., \& Charles J. (2012). Auditor Independence and Internal Information Systems Audit Quality. Business Studies Journal, 4(2), 63-84.

Yatim, P. (2010). Board Structures and the Establishment of a Risk Management Committee by Malaysian Listed Firms. Journal of Management \& Governance, 14(1), 17-36. 